\title{
Dissolution of calcium carbonate: observations and model results in the subpolar North Atlantic
}

\author{
K. Friis ${ }^{1}{ }^{*}$, R. G. Najjar ${ }^{1}$, M. J. Follows ${ }^{2}$, S. Dutkiewicz ${ }^{2}$, A. Körtzinger ${ }^{3}$, and K. M. Johnson ${ }^{3}$ \\ ${ }^{1}$ Pennsylvania State University, Department of Meteorology, 503 Walker Building, University Park, PA 16802-5013, USA \\ ${ }^{2}$ Massachusetts Institute of Technology, Department of Earth, Atmosphere and Planetary Sciences, 77 Massachusetts Av., \\ Cambridge, MA 02139, USA \\ ${ }^{3}$ Leibniz-Institut für Meereswissenschaften an der Universität Kiel, Marine Biogeochemistry, Düsternbrooker Weg 20, 24105 \\ Kiel, Germany \\ *now at: Dechema e.V., Theodor-Heuss-Allee 25, 60486 Frankfurt am Main, Germany
}

Received: 29 September 2006 - Published in Biogeosciences Discuss.: 18 October 2006

Revised: 15 January 2007 - Accepted: 8 March 2007 - Published: 20 March 2007

\begin{abstract}
We investigate the significance of in situ dissolution of calcium carbonate above its saturation horizons using observations from the open subpolar North Atlantic [sNA] and to a lesser extent a 3-D biogeochemical model. The sNA is particularly well suited for observation-based detections of in situ, i.e. shallow-depth $\mathrm{CaCO}_{3}$ dissolution [SDCCD] as it is a region of high $\mathrm{CaCO}_{3}$ production, deep $\mathrm{CaCO}_{3}$ saturation horizons, and precisely-defined pre-formed alkalinity. Based on the analysis of a comprehensive alkalinity data set we find that SDCCD does not appear to be a significant process in the open sNA. The results from the model support the observational findings by indicating that there is not a significant need of SDCCD to explain observed patterns of alkalinity in the North Atlantic. Instead our investigation points to the importance of mixing processes for the redistribution of alkalinity from dissolution of $\mathrm{CaCO}_{3}$ from below its saturation horizons. However, mixing has recently been neglected for a number of studies that called for SDCCD in the sNA and on global scale.
\end{abstract}

\section{Introduction}

Several independent studies have suggested that calcium carbonate dissolves in waters that lie above the saturations horizons for $\mathrm{CaCO}_{3}$ (e.g. Anderson and Sarmiento, 1994; Lohmann, 1995; Milliman and Droxler, 1996; Milliman et al., 1999; Chen et al., 2002; Schiebel, 2002). This shallowdepth calcium carbonate dissolution [SDCCD] has implications for our understanding of the global carbon cycle. Because of the $\mathrm{CO}_{2}$ uptake by marine and terrestrial systems, the current increase of atmospheric $\mathrm{CO}_{2}$ is half that expected

Correspondence to: $\mathrm{K}$. Friis

(friis@dechema.de) from anthropogenic releases (IPCC, 2001). Important for the marine system is that calcifying organisms at the sea surface (e.g. molluscs, corals, and calcifying plankton) have a reducing effect on the $\mathrm{CO}_{2}$ uptake capacity by turning dissolved calcium carbonate from rivers and upwelling into shells. Conventional wisdom is that the calcium carbonate shells are dissolved when they reach the saturation horizon of aragonite or calcite during sinking, which provides the excess alkalinity that can be supplied to the surface ocean via upwelling/diapycnal mixing. The impact of the SDCCD finding is that it implies a shorter time scale for the cycling of calcium carbonate within the ocean. This would have implications for feedbacks between climate, atmospheric $\mathrm{CO}_{2}$, and the marine carbon cycle.

The alkalinity distribution is thought to be a very important piece of evidence in support of SDCCD (Milliman and Droxler, 1996; Milliman et al., 1999). Like oxygen or nutrients, alkalinity is first of all a dissolved quantity in sea water, and has been recognized early to be a quantitative proxy for the concentration of calcium carbonate in seawater (a measure of the potential carbonate of lime; Dittmar, 1884). For studying the cycling of $\mathrm{CaCO}_{3}$ alkalinity has the advantage of being without much experimental or sampling error. In addition, spatial changes basically follow hydrographic changes and are otherwise continuous and gradual only. Alkalinity profiles of Wollast (1994) were used by Milliman and Droxler (1996) and Milliman et al. (1999) to estimate that 60-80\% of all $\mathrm{CaCO}_{3}$ dissolution occurs in the upper $500-1000 \mathrm{~m}$ of the water column. That the latter findings are based on traditional salinity-normalized alkalinity profiles has become clear to us from personal communication with Dr. A. W. Droxler (Department of Earth Science, Rice University, TX) and Dr. J. D. Milliman (Virginia Institute of Marine Science, The College of William \& Mary, VA). Wollast (1994) based

Published by Copernicus GmbH on behalf of the European Geosciences Union. 

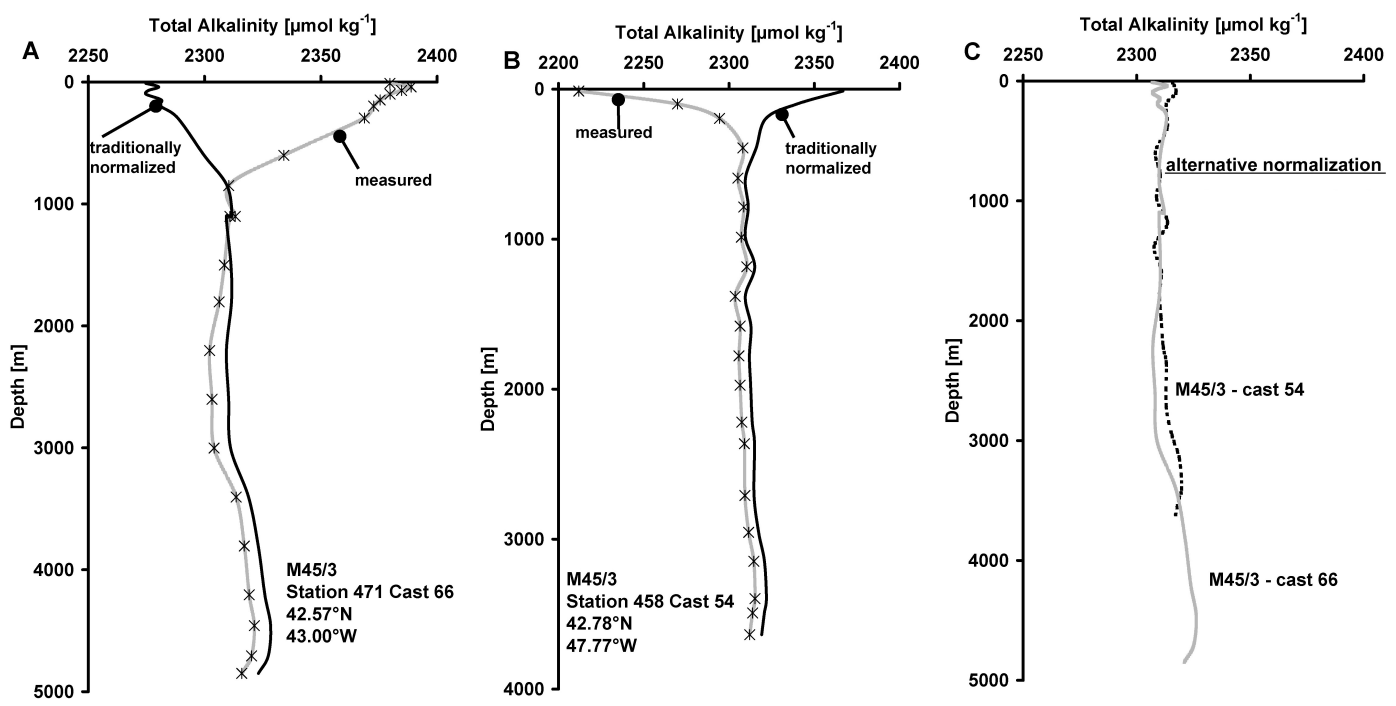

Fig. 1. Total alkalinity profiles of the subpolar North Atlantic from two casts during the Meteor cruise M45/3 in 1999 (Schott et al., 2000). Total alkalinity has been calculated from measured $C_{T}$ and $p \mathrm{H}_{T}$, (cf. data section). Also shown are salinity-normalized total alkalinities using two different transformations (cf. methods section). For a deeper understanding of traditionally normalized alkalinity profiles one needs to know about corresponding salinity profiles. Panel (A) starts off with a high sea surface salinity $(S=36.62)$ that decreases with depth, i.e. to $S=\sim 35$ at $\sim 1000 \mathrm{~m}$ and below. In contrast panel (B) starts off with a low sea surface salinity $(S=32.11)$ that increases with depth, i.e. to $S=\sim 35.0$ at $\sim 1000 \mathrm{~m}$ and below. Panel (C) shows the normalized total alkalinity profiles as based on the same measurements in panel (A) and (B) but using one region specific alkalinity-salinity relationship from sea surface measurements.

his study on averaged alkalinity profiles in the North Atlantic, North Pacific, and South Indian Ocean as provided by Takahashi et al. (1980) from the GEOSECS expeditions. It is also obvious that Wollast (1994) used traditionally normalized alkalinity profiles by comparing GEOSECS data (as provided by Schlitzer, 2000) to Fig. 2 in Wollast (1994).

However, the use of traditional salinity normalization can lead to biogeochemical misinterpretations as shown in Fig. 1 and in more general terms in Friis et al. (2003). Panel (A) shows that traditional normalization can create nutrient-like profiles for alkalinity. What is frequently neglected is that the traditional normalization can also lead to decreases of alkalinity with depth (panel B), which causes some problems if alkalinity is interpreted strictly along the lines of nutrient cycling. The reason for the ambiguous results of the traditional normalization is that other non-biogenic processes, like advection, diffusion, and riverine input, are not removed by it. If the salinity normalization is done properly, like in panel (C) of Fig. 1, there is no indication of a strong alkalinity change in the upper $2000-3000 \mathrm{~m}$ of the water column and therefore no need to invoke SDCCD.

Based on global analyses of alkalinity data, recent publications claim evidence of SDCCD (Feely et al., 2002; Sabine et al., 2002; Chung et al., 2003; Feely et al., 2004; we hereafter refer to these publications as $\mathrm{GA}^{2002}$ ). $\mathrm{GA}^{2002}$ get around the problems of normalization either by not using salinity normalization or by calculations that cancel errors from traditional normalization to a major extent. $\mathrm{GA}^{2002}$ find peaks of excess alkalinity (with respect to preformed alkalinity) closest to the saturation horizons of $\mathrm{CaCO}_{3}$, which in most parts of the ocean is much deeper than $1000 \mathrm{~m}$.

The present article evaluates the potential of SDCCD in the open subpolar North Atlantic [sNA] on the basis of total alkalinity measurements and to lesser extent numerical modeling. Carbonate dissolution in marginal sediments of the continents is not considered. The open sNA region is particularly well suited for the detection of SDCCD as it is known as a region of high $\mathrm{CaCO}_{3}$ production (Milliman, 1993; Holligan et al., 1993) and exhibits the deepest saturation horizons of calcium carbonate in the ocean (e.g. Broecker and Peng, 1983; Chung et al., 2003). Additionally, the interpretation of alkalinity appears rather straightforward, as the sNA has preformed alkalinity values that can be characterized precisely (Friis et al., 2003). Our analysis does not assume a priori that the ocean follows an isopycnal circulation, nor do we assume that water mass formation takes place at the sea surface only, as was assumed in $\mathrm{GA}^{2002}$.

In the following we first show that the regional salinity normalization for total alkalinity of Friis et al. (2003) improves the interpretation of alkalinity variations in the water column. Increasing concentrations of salinity-normalized alkalinities at greater depth are then further investigated by using silicate as a bottom-up tracer for Antarctic Bottom Water [AABW]. Existing knowledge of North Atlantic Deep Water [NADW] formation leads us to conclusions about SDCCD in the sNA based on observations. These results are then 
supported by output from an ocean general circulation model for the North Atlantic. The model features a biogeochemical routine for the cycling of calcium carbonate that does not allow for SDCCD. The combined observation/model approach leads us to an interpretation of excess alkalinity that differs substantially from that of $\mathrm{GA}^{2002}$.

\section{Data}

We make use of a high quality data set of the sNA consisting of 6101 individual samples of total alkalinity, $A_{T}$, and total inorganic carbon, $C_{T}$. The data set is merged from ten research cruises during the years 1996 to 2003 (Fig. 2). Nine of the cruises were on board the German RV METEOR (M36/2, M39/2-3-4, M45/2-3, M50/14, M59/2), and one was on board the German RV GAUSS (G350/1). Most of the cruise reports of the RV METEOR are available online (http://www.ifm-geomar.de/index.php? id=meteor_berichte $\& \mathrm{~L}=1)$. All $A_{T}$ and $C_{T}$ measurements were performed by following standard operating procedures (DOE, 1994) and were quality controlled by using certified reference materials (Dickson, 1990). $A_{T}$ values from the M45 cruise were calculated from $C_{T}$ and spectrophotometric $p \mathrm{H}_{T}$ measurements (Friis et al., 2004) with the free computer program CO2SYS (Lewis and Wallace, 1998) using the apparent dissociation constants $K_{1}$ and $K_{2}$ of Mehrbach et al. (1973) as refitted by Dickson and Millero (1987) and the $\mathrm{HSO}_{4}^{-}$constant according to Dickson (1993). The overall accuracy assessment of the $\mathrm{CO}_{2}$ parameters is about $\pm 6 \mu \mathrm{mol}$ $\mathrm{kg}^{-1}$ in $A_{T}$ and $\pm 3 \mu \mathrm{mol} \mathrm{kg}-1$ in $C_{T}$ for the entire dataset (individual cruise accuracy/precision estimates are sometimes better).

\section{Methods}

\subsection{Observations}

Alkalinity normalizations: For biogeochemical interpretations, alkalinity is normalized to a constant salinity to make it independent of the concentrating and diluting effects of evaporation and precipitation, respectively. The traditional normalization is a simple alkalinity transformation using the following equation:

$n A_{T}=\left(A_{T}^{\text {meas }} / S^{\text {meas }}\right) \cdot S^{\text {ref }}$.

In our case $S^{\text {ref }}$ is chosen to be 35 , as usual. The regional normalization is based on regional relationships between alkalinity and salinity at the sea surface and allows an empirical term representing river input and/or upwelling $\left(A_{T}^{S=0}\right)$. The regional normalization is done by the following transformation:

$A_{T}^{e S}=\left(A_{T}^{\text {meas }}-A_{T}^{S=0}\right) / S^{\text {meas }} \cdot S^{\text {ref }}+A_{T}^{S=0}$

using $A_{T}^{S=0}=728 \mu \mathrm{mol} \mathrm{kg}^{-1}$ (Friis et al., 2003).

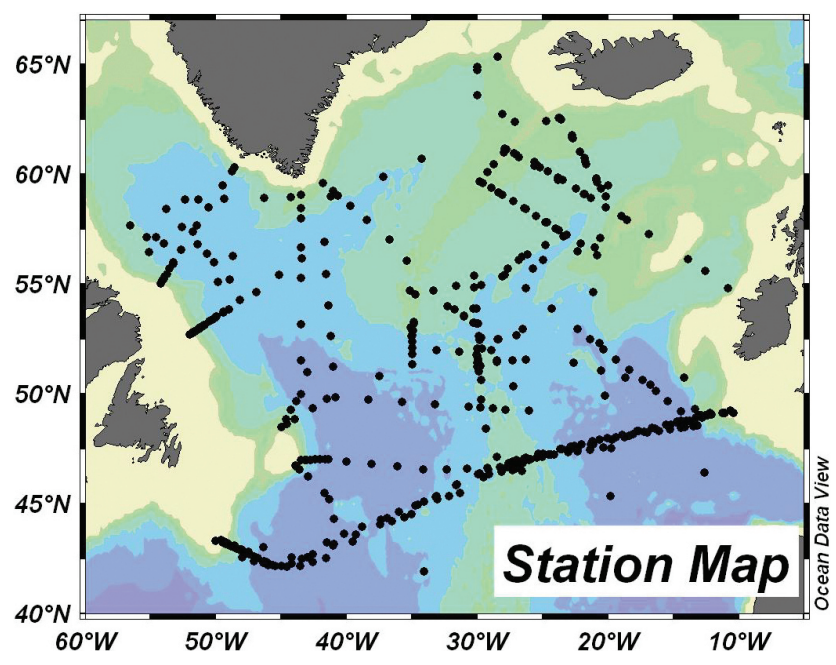

Fig. 2. Station map of all hydrographic stations of the subpolar North Atlantic Gyre that were included in this study. Also shown are the locations of the five subpolar basins (Irminger Basin, Labrador Basin, Newfoundland Basin, Iceland Basin, and West European Basin).

Calculation of the $\mathrm{CaCO}_{3}$ saturation state $[\Omega]$ : The $\Omega$ calculations were made with the program CO2SYS (Lewis and Wallace, 1998) as described above using measurements of $A_{T}, C_{T}, \mathrm{pH}_{T}$.

\subsection{Numerical modeling}

We use the MIT ocean general circulation model (Marshall et al., 1997a, b), which is configured globally at coarse resolution $(2.8 \times 2.8$ degrees, 15 vertical levels $)$ to simulate the cycling of $\mathrm{CaCO}_{3}$. Forcing, configuration, and run of the model are exactly the same as described in more detail in Friis et al. (2006). We apply a highly idealized parameterization of net community production, limited by the availability of light and phosphate:

$\mathrm{B}=\mathrm{a} \cdot \mathrm{I} /\left(\mathrm{I}+\mathrm{K}_{\mathrm{I}}\right) \cdot \mathrm{PO}_{4} /\left(\mathrm{PO}_{4}+\mathrm{K}_{\mathrm{PO} 4}\right)$

where $\mathrm{a}=3 \mu \mathrm{M} \mathrm{P} \mathrm{yr}^{-1}$ is the maximum community production, and the half-saturation coefficients are $\mathrm{K}_{\mathrm{I}}=30 \mathrm{~W} \mathrm{~m} \mathrm{~m}^{-2}$, and $\mathrm{K}_{\mathrm{PO} 4}=0.5 \mu \mathrm{M}$. For the rain ratio, or production of calcium carbonate relative to carbon incorporated in soft tissue, we use the region-specific estimates of Sarmiento et al. (2002). Further, we assume that the dissolution of $\mathrm{CaCO}_{3}$ only occurs below the saturation horizon of calcite. $\mathrm{CaCO}_{3}$ sinks from the euphotic zone with an assumed speed of $100 \mathrm{~m}$ $\mathrm{d}^{-1}$ and dissolves based on the local saturation state with respect to calcite:

$\Omega=\left[\mathrm{Ca}^{2+}\right]\left[\mathrm{CO}_{3}^{2-}\right] / \mathrm{K}_{\mathrm{sp}}$

where $\mathrm{K}_{\mathrm{sp}}(T, S, p)$ is the solubility product from Mucci (1983) with the pressure dependency of Millero et al. (1995). 

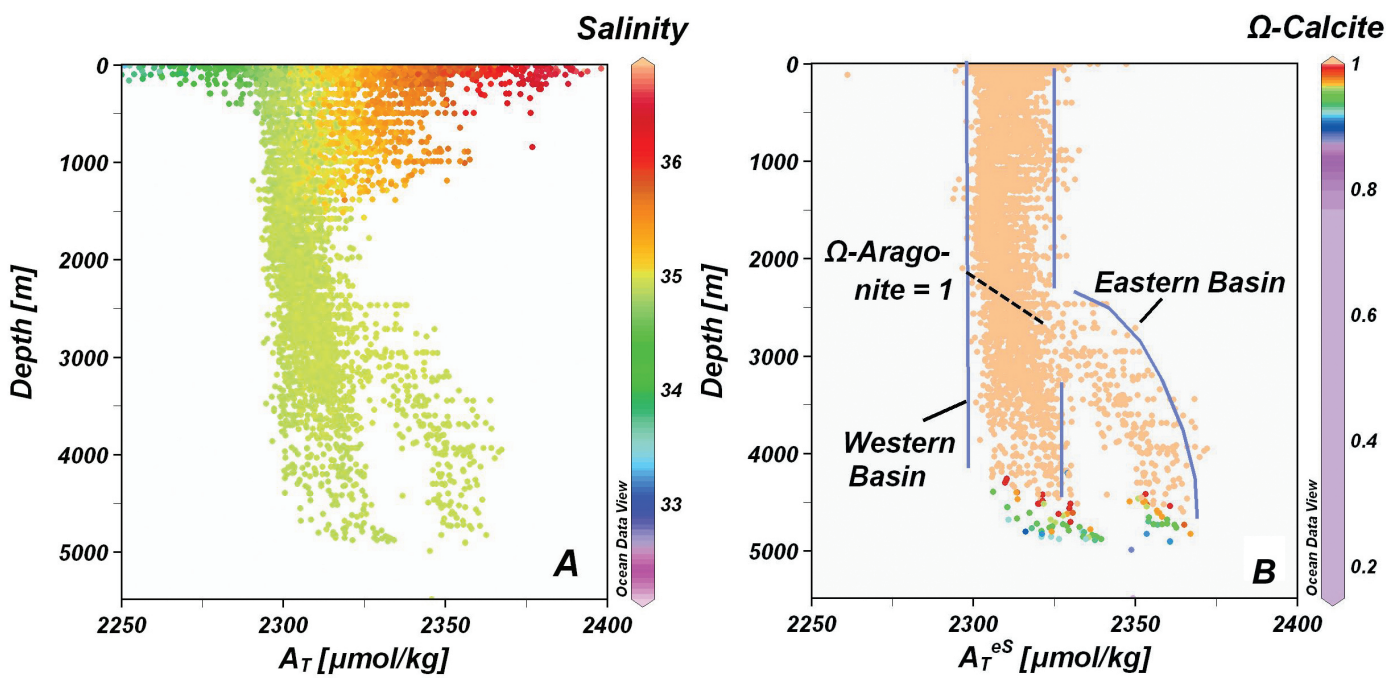

Fig. 3. Hydrographic profiles of alkalinity $\left(A_{T}\right)$ from all measurements, color-coded with salinity (A). (B) Normalized alkalinities $\left(A_{T}^{e S}\right)$ using a regional normalization method. The color-coded calcite saturation state $(\Omega)$ is calculated from measured alkalinity and total dissolved inorganic carbon (cf. methods). The position of the aragonite saturation horizon is also shown.

The carbonate system speciation is solved according to Follows et al. (2006). The concentration of $\mathrm{Ca}^{2+}$ is determined from a conservative relationship with salinity (DOE, 1994):

$\left[\mathrm{Ca}^{2+}\right]=0.01028 \mathrm{~S} / 35$

where $\left[\mathrm{Ca}^{2+}\right]$ is the concentration in $\mathrm{mol} \mathrm{kg} \mathrm{kg}^{-1}$. Because calcium is a major constituent of sea water, dissolution of $\mathrm{CaCO}_{3}$ hardly influences the concentration of $\mathrm{Ca}^{2+}$, which is different for the $\mathrm{CO}_{3}^{2-}$ concentration. The dissolution of calcium carbonate occurs only below the saturation horizon $(\Omega<1)$, following dissolution kinetics from Kier (1980):

Calcite $^{\text {dissolution rate }}\left(\%\right.$ day $\left.^{-1}\right)=7.177(1-\Omega)^{4.54}$

If calcium carbonate reaches the bottom of the model ocean and $\Omega<1$, all particles are immediately dissolved in that grid cell. If carbonate particles reach the bottom layer and $\Omega>1$, thermodynamically they should be buried. However, to maintain the global budget of alkalinity in a simplified manner, we balance such loss due to sedimentation with a source of equal magnitude in the local surface ocean.

For diagnostic reasons we also introduce a bottom-uptracer, $\mathrm{M}$, which illustrates how a tracer, like alkalinity, that is created below the saturation horizon can be transported upwards across the saturation horizon. At each time step, $\mathrm{M}$ is set to 100 everywhere below the calcite saturation horizon and to zero in the surface layer:

$M=0(0-50 m)$

$M=100$ if $\Omega<1$

The tracer is transported by the flow field and mixing coefficients of the circulation model.

\section{Results and discussion}

4.1 Tracing calcium carbonate dissolution from observations

Figure 3 shows alkalinity profiles of the full sNA data set. In panel (A), measured total alkalinities at the sea surface are widely spread and correlated with salinity (colored scale). The high salinities in the upper layer down to about $900 \mathrm{~m}$ identify the North Atlantic Current; low surface salinities identify cold waters of northern origin; somewhat higher alkalinities around $1000 \mathrm{~m}$ are bound to saline and warm Mediterranean Intermediate Water [MDIW]. At about $2500 \mathrm{~m}$, alkalinities split into two distinct branches: the one with lower alkalinities corresponds to samples from the western basin, and the one with higher alkalinities to observations of the eastern basin. The western basin branch shows only very slight alkalinity increases with depth when reaching the aragonite saturation horizon $(\Omega=1$, panel B), whereas the eastern basin branch exhibits comparably strong increases of $\sim 45 \mu \mathrm{mol} \mathrm{kg}^{-1}$ from $3000 \mathrm{~m}$ to $5000 \mathrm{~m}$ depth.

Panel (B) shows the regionally normalized alkalinities, $A_{T}^{e S}$, which are much closer together at the sea surface and the subsurface than in panel (A). The $A_{T}^{e S}$ profile hardly shows any increase from the surface down to about $2500 \mathrm{~m}$. This is in agreement with the two individual station profiles shown above in Fig. 1C. The comparably broad profile structure in Fig. 3B can be explained by a variety of factors: the given precision of the total alkalinity measurements, the accuracy of the alkalinity-salinity sea surface relationship used for the regional normalization, the overall accuracy from cruise-to-cruise, and specific hydrographic features within the sNA that are not easily resolved by the 
regional normalization. For example, the width of individual branches below $2500 \mathrm{~m}$ decreases by about one third if an individual cruise is considered only. Also, around $1000 \mathrm{~m}$, the alkalinities of the MDIW have slightly higher concentrations because the alkalinity-salinity relationship at the sea surface is different between the sNA and the Mediterranean Sea.

In both panels of Fig. 3, measured and normalized alkalinities at depths greater than $1500 \mathrm{~m}$ do not differ much from each other as their salinities are all close to the reference salinity of 35 making the effect of the normalization procedure very small regardless what method is chosen. In Fig. 3, the saturation state of calcite, the less soluble form of calcium carbonate, is shown color-coded on the alkalinity profile. Calcite is, by far, the dominant mineral produced by plankton in the sNA (Milliman, 1993; Holligan et al., 1993). Conventional wisdom would assume that significant dissolution of calcite is restricted to below its saturation horizon, which is found at depths around $4500 \mathrm{~m}$. Consistent with this, the western basin branch shows nearly no variation above the calcite saturation horizon.

The difference between the eastern and the western branches in Fig. 3 is due to bottom water circulation. The bottom waters of the eastern basin are not dominated by water masses of northern origin but represent the remnants of $\mathrm{AABW}$. The AABW is very old, has a long pathway to the North, and is significantly more corrosive to aragonite and calcite. When AABW reaches the sNA it is enriched in alkalinity from calcium carbonate dissolution along its pathway. $\mathrm{AABW}$ is the southerly mixing component for the formation of NADW, and so carries a high alkalinity signal into the eastern sNA. The three northern mixing components of NADW are Labrador Sea Water, Denmark Straight Overflow Water [DSOW] and Iceland Scotland Overflow Water (Dickson and Brown, 1994).

In the northern hemisphere AABW can be traced most directly by its characteristically high silicate concentration (Dickson and Brown, 1994; Andrié et al., 2003) of about $45 \mu \mathrm{mol} \mathrm{kg}-1$. This concentration is nearly constant (Schlitzer, 2000) as AABW flows from the western to the eastern basin through the Vema Fracture Zone at about $11^{\circ} \mathrm{N}$. For the purpose of alkalinity studies in the sNA, silicate is ideal as a bottom-up-tracer for the diapycnal mixing of waters from below the calcite saturation horizon with waters above the saturation horizon. As shown in Fig. 4, the northern component silicate concentration between $1100 \mathrm{~m}$ and $2000 \mathrm{~m}$ is about $11 \pm 2 \mu \mathrm{mol} \mathrm{kg}-1$. This rather homogenous source value is determined by silicate concentrations at the sea surface during winter, when the northern components are formed, and a complete dissolution of biogenic silica (opal) above $1100 \mathrm{~m}$. Complete opal dissolution is well supported by experimental findings of its efficient redissolution in the euphotic zone (Bidle and Azam, 1999; Rickert et al., 2002), earlier model studies (Nelson et al., 1995), the absence of biogenic opal in the sediments (Anderson et al., 1986; NOAA, 2004), and the uniform silicate concen-

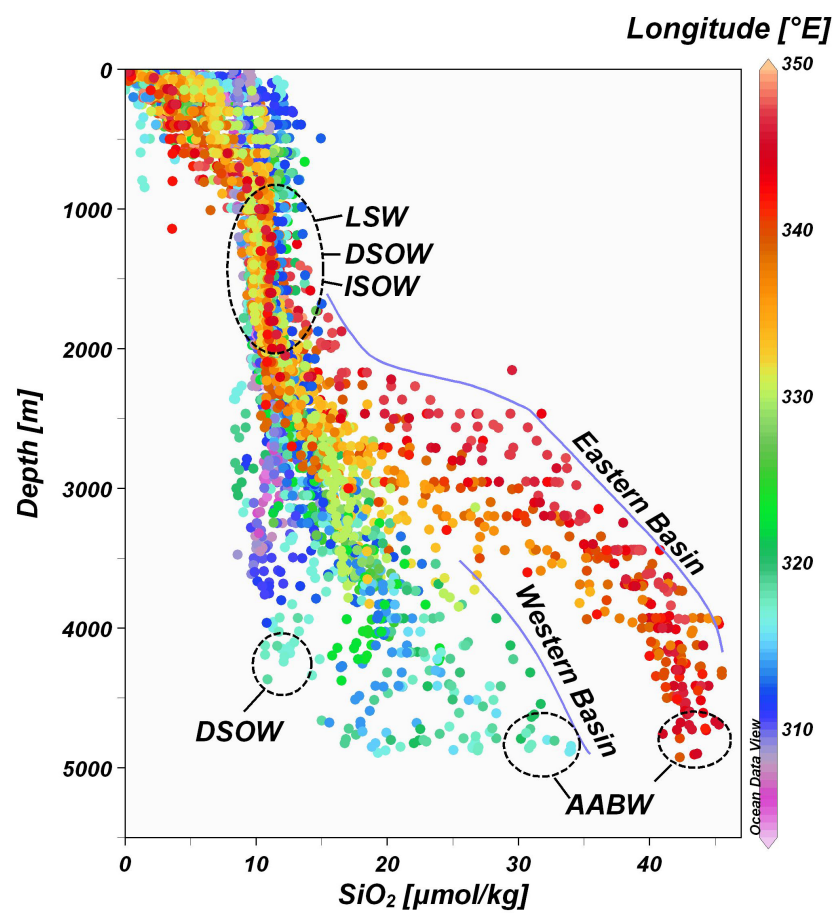

Fig. 4. Silicate profiles of the subpolar North Atlantic during the years 1996 to 2003 . The depth range from $1000 \mathrm{~m}$ to $2200 \mathrm{~m}$ reflects Labrador Sea Water [LSW] in the Labrador and the West European Basin, Denmark Straight Overflow Water [DSOW] in the Reykjanes Basin, and Iceland Scotland Overflow Water [ISOW] in the Iceland Basin.

trations within the intermediate layer (1100-2000 m) itself, which would not be maintained if a significant amount of opal was dissolved in this layer (Anderson and Sarmiento, 1994). Due to the homogenous silicate concentration in the northern intermediate and deep water components and the 3.5 times higher concentrations in southern bottom water component, silicate, compared to PO, NO, or salinity, is the superior hydrographic tracer for quantifying the mixing of AABW with the northern endmembers of the NADW.

Figure 4 shows that the bottom water silicate concentrations of the western basin are high compared to surface and intermediate waters, though not as high as the bottom waters of the eastern basin. The origin of the high silicate concentrations in the bottom water of the western basin is also AABW, as can be inferred from the eWOCE atlas (sections A17 and A20; Schlitzer, 2000), but its influence is much more diluted than in the eastern basin. The comparably wide concentration range within the bottom waters of the western basin reflects the dominating influence of DSOW near the North American Shelf.

The strong influence of the AABW on the sNA alkalinity profiles is shown in Fig. 5, where normalized alkalinity $A_{T}^{e S}$ is plotted vs. silicate (depth is color-coded). The silicate increase from 0 to about $11 \mu \mathrm{mol} \mathrm{kg}-1$, following depth, is 


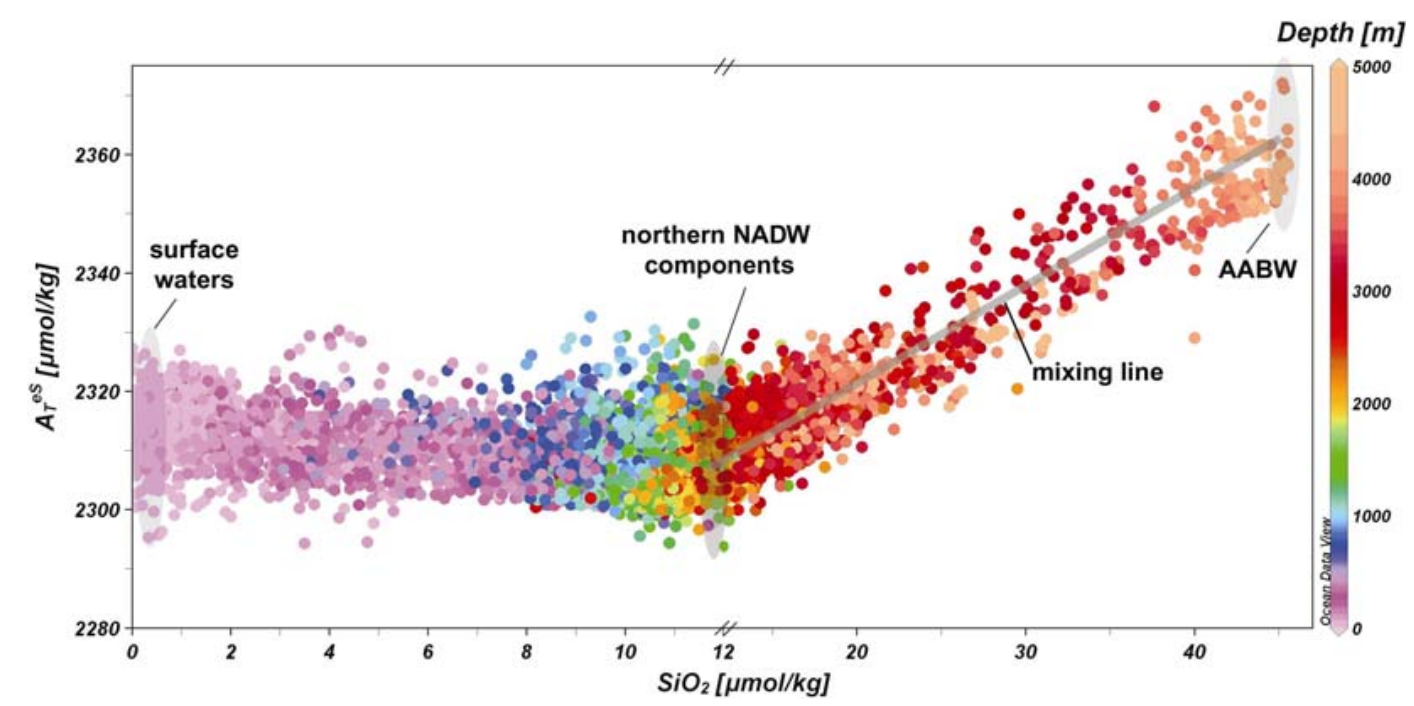

Fig. 5. Salinity adjusted alkalinity by the regional method $\left(A_{T}^{e S}\right)$ vs. silicate concentration. Note scale change at $12 \mu \mathrm{mol} \mathrm{kg}^{-1}$. Colored scale is depth.

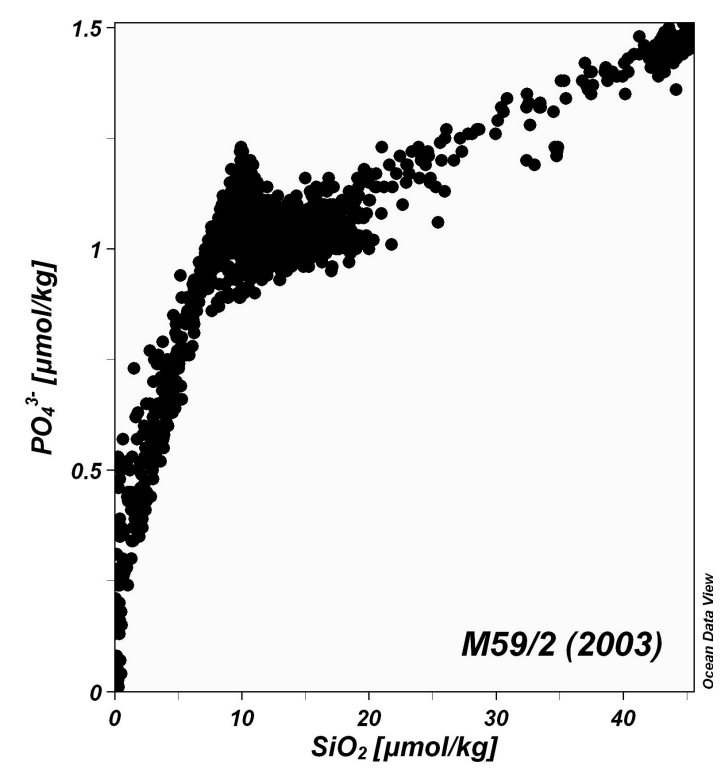

Fig. 6. Phosphate vs. silicate plot of the M59/2 cruise in the entire sNA. The phosphate-silicate relation shows concurrent linear increases of both parameters with depth with a distinct change of the relationship at about $12 \mu \mathrm{mol} \mathrm{kg}-1$. According to the change the plot is divided into two parts: (I) Silicate concentrations $<12 \mu \mathrm{mol}$ $\mathrm{kg}^{-1}$ reflect phosphate and silicate changes from particle remineralization and dissolution in the sNA; (II) silicate concentrations $>12 \mu \mathrm{mol} \mathrm{kg}{ }^{-1}$, concentration changes mainly indicate diapycnal mixing between lower-concentration northern NADW components with higher-concentration AABW.

not accompanied by an alkalinity increase, but rather a very slight decrease. Such a decrease would in fact be expected because it is known from laboratory experiments (Brewer and Goldman, 1976) that remineralization of organic material lowers alkalinity by an amount about equal to the amount of nitrate released. However, the alkalinity decrease should be about twice as large $\left(A_{T}^{e S}\right.$ decreases by $9 \mu \mathrm{mol}$ $\mathrm{kg}^{-1}$ whereas nitrate increases by $18 \mu \mathrm{mol} \mathrm{kg}{ }^{-1}$ ), and the discrepancy could be interpreted as evidence for SDCCD. The model simulations, discussed below, however, suggest that mixing can provide a substantial fraction of this missing alkalinity. It is interesting to see that due to the regional normalization procedure such small negative effects can be picked up from the observed distribution. The remineralization phenomenon is not masked or compensated by a strong SDCCD. For silicate concentrations from $12 \mu \mathrm{mol} \mathrm{kg}^{-1}$ to $45 \mu \mathrm{mol} \mathrm{kg}-1$ alkalinities follow a straight mixing line of the northern NADW components and the AABW. If significant amounts of calcium carbonate minerals were dissolved in situ, one would expect an increase in alkalinity along a bow on top of the mixing line (Anderson and Sarmiento, 1994), which is not observed.

We also note that for in situ dissolution of $\mathrm{CaCO}_{3}$ one would independently expect alkalinity increases with depth along with phosphate increases from remineralization. - In any case remineralization of organic matter needs to be involved to create low $p \mathrm{H}$ environments for the dissolution of $\mathrm{CaCO}_{3}$. But as commonly known and inferable from looking at Figs. 5 and 6 most of the phosphorus remineralization takes place between the surface and about $2500 \mathrm{~m}$ depth. Since normalized total alkalinity does not increase in this upper part of the water column, it appears, from different observational perspectives, that SDCCD is a phenomenon that is neither easily explained nor deduced from observations. 


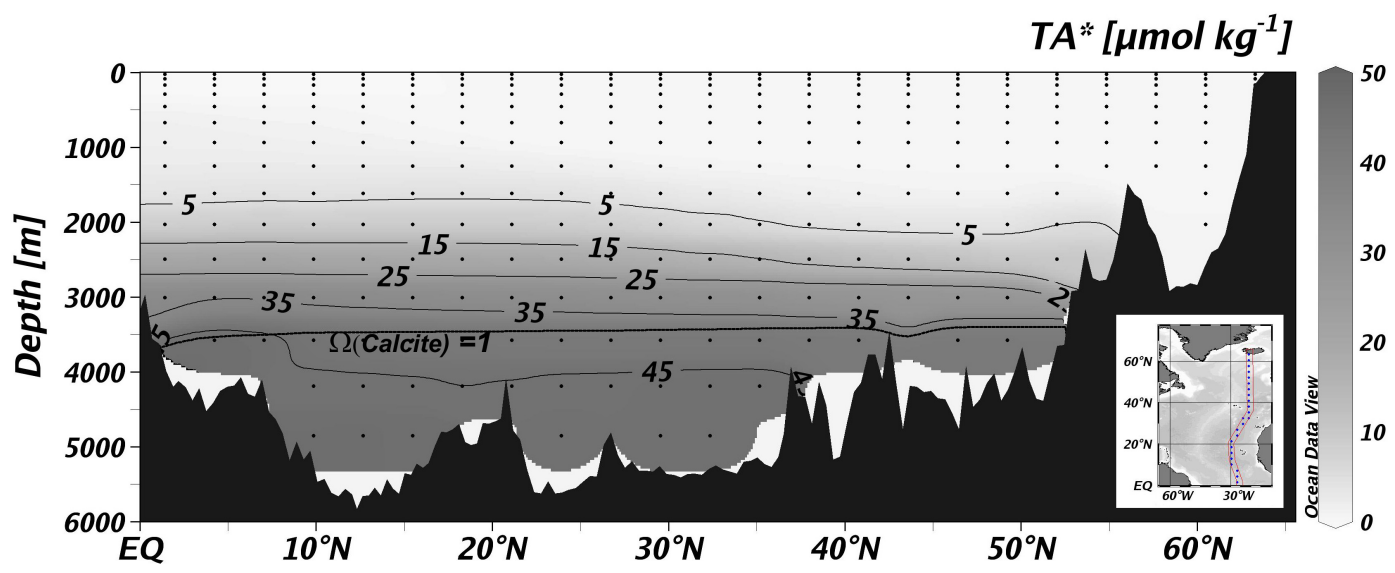

Fig. 7. Model results from the MIT ocean model, output as annual mean. - Meridional section of excess dissolved $\mathrm{CaCO}_{3}, \mathrm{TA}^{*}$, and the saturation horizon of calcite in the North Atlantic along A16. TA* is defined as alkalinity from dissolution of $\mathrm{CaCO}_{3}$ below the surface layer and is normalized to the moles of calcium carbonate that have been dissolved.

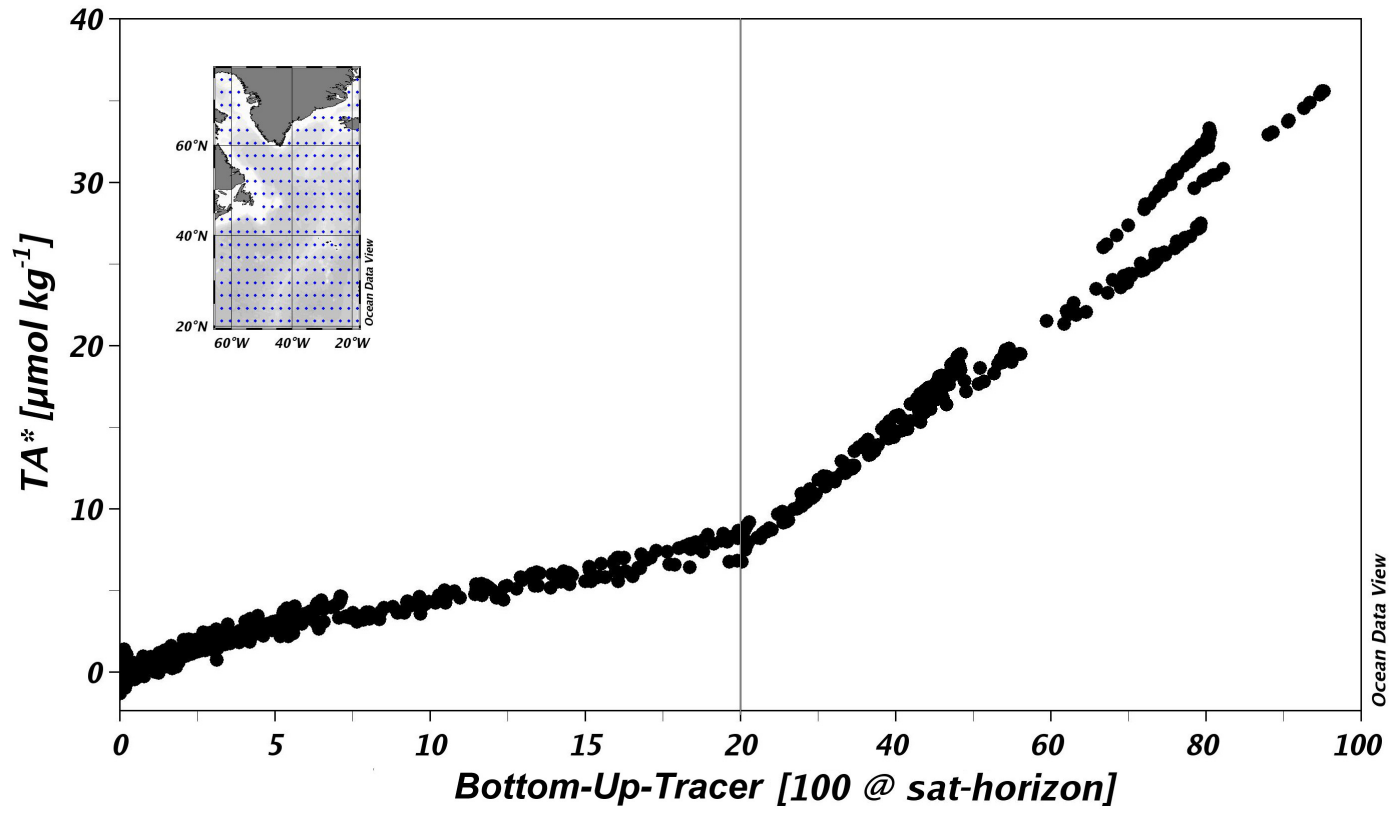

Fig. 8. Model results from the MIT ocean model, output as annual mean. - TA* vs. a diagnostic bottom-up-tracer (cf. text).

\subsection{Model simulations}

To summarize the observational analysis, we find that mixing can explain the alkalinity distribution in the sNA without a significant need for SDCCD. We now use the results from our model simulations to look at TA*, which is the subsurface increase in the dissolved calcium concentration due to the dissolution of $\mathrm{CaCO}_{3}$ (multiply by two to get the corresponding alkalinity increase). $\mathrm{TA}^{*}$ is called $\triangle \mathrm{TA}^{\mathrm{CaCO} 3}$ by Chung et al. (2003) and $\Delta \mathrm{CaCO}_{3}$ by Feely et al. (2004). See Friis et al. (2006) for the computation of TA* in the model.

In Fig. 7 we show TA* from the model along the meridional A16 section throughout the North Atlantic. The same meridional section, based on observations can be found in Chung et al. (2003) (therein Fig. 7). The model simulates $\mathrm{TA}^{*}$ values in deep water that are about a factor of two greater than the observations, which we believe is due to deep-water ventilation rates that are too low. The model $100 \%$ calcite saturation horizon is also too shallow by about $1 \mathrm{~km}$. These deficiencies need to be kept in mind when using the model to evaluate the conclusions of our observational analysis. The model simulates TA* values $\sim 1000 \mathrm{~m}$ above the saturation horizon that are about half of those at the saturation horizon. On the other hand, in the upper water column (0-1800 $\mathrm{m}$ depth), the transport of TA* from below the saturation horizon is not shown to be a very important process. 
The transition zone between the saturation horizon and the upper water column, where the transport of TA* appears to be significant, is about $2000 \mathrm{~m}$ thick. This is in fact the length scale of the transition zone that can be identified in the observations, i.e. the eastern basin branch of total alkalinity shown in Fig. 3. This supports our inference from the observations that the increase in alkalinity with depth in the deep portion of the eastern basin is due to mixing.

In Fig. 8 we show TA* vs. the diagnostic bottom-up-tracer. Figure 8 is analogous to Fig. 5, where silicate has been used as a bottom-up-tracer for observational analysis. As in Fig. 5, the break in the curve occurs at about $2000 \mathrm{~m}$. The slope in Fig. 8 is consistently positive as we have compensated for remineralization effects in the TA* tracer (Friis et al., 2006). So the model resembles the pattern from observations to a major extent, without relying on any SDCCD process. The alkalinity deficit of $9 \mu \mathrm{mol} \mathrm{kg}-1$ between 0 and $2000 \mathrm{~m}$ discussed in regard to Fig. 5 can easily be accommodated by mixing: we find $\mathrm{TA}^{*}$ values of about $5 \mu \mathrm{mol} \mathrm{kg}^{-1}$ (i.e., $10 \mu \mathrm{mol} \mathrm{kg}{ }^{-1}$ of alkalinity) at around $2000 \mathrm{~m}$ (Figs. 7 and 8). This interpretation is tempered by the fact that our saturation horizon is too shallow. We therefore cannot completely rule out SDCCD, but after removing mixing effects, the TA* values are getting very close to measurement precision, leaving dissolution error estimates as large as the signal.

\section{Conclusions}

In summary, the analysis of a comprehensive alkalinity data set and numerical model results do not indicate any significant need for in situ or shallow-depth dissolution of $\mathrm{CaCO}_{3}$ in order to explain observed patterns of alkalinity in the sNA. The observed pattern can instead be explained by (I) salinitydependent variations of alkalinity at the sea surface and subsurface and (II) transport of dissolved $\mathrm{CaCO}_{3}$ from below the saturation horizon into depths that are above the saturation horizon of $\mathrm{CaCO}_{3}$. However, as pointed out before, the results of our model study could be improved in terms of the strength of the TA* signal. We believe that the TA* distribution would improve if the model circulation was improved, and we suggest that further model studies be conducted with other circulation models.

Our results on the occurrence of SDCCD in the North Atlantic raise questions about previous suppositions and recent global analyses based on high-quality alkalinity observations. Based on our knowledge of NADW formation, we conclude that the assumption of a complete isopycnal circulation, which was used in $\mathrm{GA}^{2002}$, can be flawed if water mass formation takes place in the ocean interior. Additionally, we note that for other ocean regions deep water upwelling, isopycnal mixing and diapycnal mixing should have a considerable impact on the alkalinity distribution, especially in areas with shallow saturation horizons (Friis et al., 2006).
Acknowledgements. We want to thank R. A. Feely, K. Lee and A. G. Dickson for critical comments on an earlier version of the manuscript. We also want to thank A. Olson, L. Anderson and U. Riebesell for their review/editorial advice. K. Friis and R. G. Najjar were supported by NOAA grant GC02-367b and NSF grant OCE-0136621. M. J. Follows and S. Dutkiewicz are also grateful for support from NOAA and NASA. The data collection and analytical work by A. Körtzinger, K. Friis, K. M. Johnson, L. Mintrop, C. Neill, and colleagues is based on funding from the Deutsche Forschungsgemeinschaft, grant SFB-460, sub project A5, PIs J. Duinker and D. W. R. Wallace.

Edited by: U. Riebesell

\section{References}

Adcroft, A., Hill, C., and Marshall, J.: Representation of topographyby shaved cells in a height coordinate ocean model, Mon. Weather Rev., 125, 2293-2315, 1997.

Anderson, L. G., Hall, P. O. J., Iverfeldt, A., Vanderloeff, M. M. R., Sundby, B., and Westerlund, S. F. B.: Benthic respiration measured by total carbonate production, Limnol. Oceanogr., 31, 319-329, 1986.

Anderson, L. A. and Sarmiento, J. L.: Redfield ratios of remineralization determined by nutrient data analysis, Global Biogeochem. Cycles, 8, 65-80, 1994.

Andrié, C., Gouriou, Y., Bourlès, B., Ternon, J.-F., Braga, E. S., Morin, P., and Oudot, C.: Variability of AABW properties in the equatorial channel $35^{\circ} \mathrm{W}$, Geophys. Res. Lett., 30, 8007, doi:10.1029/2002GL015766, 2003.

Bidle, K. D. and Azam, F.: Accelerated dissolution of diatom silica by marine bacterial assemblages, Nature, 397, 508-512, 1999.

Brewer, P. G. and Goldman, J. C.: Alkalinity changes generated by phytoplankton growth, Limnol. Oceanogr., 21, 108-117, 1976.

Chen, C.-T. A.: Shelf-vs. dissolution-generated alkalinity above the chemical lysocline, Deep-Sea Res. II, 49, 5365-5375, 2002.

Chung, S. N., Lee, K., Feely, R. A., Sabine, C. L., Millero, F. J., Wanninkhof, R., Bullister, J. L., Key, R. M., and Peng, T.-H.: Calcium carbonate budget in the Atlantic Ocean based on water column inorganic carbon chemistry, Global Biogeochem. Cycles., 17, 1093, doi:10.1029/2002GB002001, 2003.

Dittmar, W.: Report on the scientific results of the voyage of HMS CHALLENGER during the years 1873-76, Physics and Chemistry, Vol. I, published by order of her Majesty's Government, UK, 1884.

Dickson, A. G.: The oceanic carbon dioxide system: planning for quality data, JGOFS News, 2, 2, 1990.

Dickson, A. G.: pH buffers for sea water media based on the total hydrogen ion concentration scale, Deep-Sea Res., 40A, 107-118, 1993.

Dickson, A. G. and Millero, F. J.: A comparison of the equilibrium constants for the dissociation of carbonic acid in seawater media, Deep Sea Res., 34A, 1733-1743, 1987.

Dickson, R. R. and Brown, J.: The production of North Atlantic Deep Water: Sources, rates, and pathways, J. Geophys. Res. C, 99, 12 319-12341, 1994.

DOE: Handbook of methods for the analysis of various parameters of the carbon dioxide system in sea water, edited by: Dickson, A. 
G. and Goyet, C., Version 2.0, U.S. Department of Energy, Oak Ridge Natlional Laboratory, Oak Ridge, Tennessee, 1994.

Feely, R. A., Sabine, C. L., Lee, K., Millero, F. J., Lamb, M. F., Greeley, D., Bullister, J. L., Key, R. M., Peng, T.-H., Kozyr, A., Ono, T., and Wong, C. S.: In situ calcium carbonate dissolution in the Pacific Ocean, Global Biogeochem. Cycles, 16, 1144, doi:10.1029/2002GB001866, 2002.

Feely, R. A., Sabine, C. L., Lee, K., Berelson, W., Kleypas, J., Fabry, V. J., and Millero, F. J.: Impact of anthropogenic $\mathrm{CO}_{2}$ on the $\mathrm{CaCO}_{3}$ system in the oceans, Science, 305, 362-366, 2004.

Follows, M. J., Dutkiewicz, S., and Ito, T.: On the solution of the carbonate system in ocean biogeochemistry models, Ocean Modelling, 12, 290-301, 2006.

Friis, K., Najjar, R. G., Follows, M. J., and Dutkiewicz, S.: Dissolution of calcium carbonate: A model perspective, Global Biogeochem. Cycles., 20, GB4019, doi:10.1029/2006GB002727, 2006.

Friis, K., Körtzinger, A., and Wallace, D. W. R.: The salinity normalization of marine inorganic carbon chemistry data, Geophys. Res. Lett., 30, 1085, doi:10.1029/2002GL015898, 2003.

Friis, K., Körtzinger, A., and Wallace, D. W. R.: Spectrophotometric $\mathrm{pH}$ measurement in the ocean: requirements, design and testing of an autonomous charge-coupled device detector system, Limnol. Oceanography: Methods, 2, 126-136, 2004.

Goyet, C., Coatanoan, C., Eischeid, G., Amaoka, T., Okuda, K., Healy, R., and Tsunogai, S.: Spatial variation of total $\mathrm{CO}_{2}$ and total alkalinity in the northern Indian Ocean: A novel approach for the quantification of anthropogenic $\mathrm{CO}_{2}$ in seawater, J. Mar. Res., 57(1), 135-163, 1999.

Holligan, P. M., Fernandez, E., Aiken, J., Balch, W. M., Boyd, P., Burkill, P. H., Finch, M., Groom, S. B., Malin, G., Müller, K., Purdie, D. A., Robinson, C., Trees, C. C., Turner, S. M., and Vanderwal, P. A.: Biogeochemical study of the coccolithophore, Emiliania-Huxleyi, in the North-Atlantic, Global Biogeochem. Cycles, 7, 879-900, 1993.

IPCC: Part C: The forcing agents that cause climate change, in: Climate change 2001: The scientific basis, edited by: Albritton, D. L., Meira Filho, L. G., Cubasch, U., et al., Cambridge University Press, Cambridge, United Kingdom and New York, USA, 36-46, 2001.

Kier, R. S.: The dissolution kinetics of biogenic calcium carbonates in seawater, Geochim. Cosmochim. Acta, 44, 241-252, 1980.

Lewis, E. and Wallace, D. W. R.: CO2SYS - Program developed for the $\mathrm{CO}_{2}$ system calculations, edited by: Carbon Dioxide Information Analysis Center, Report ORNL/CDIAC-105, Oak Ridge National Laboratory, Oak Ridge, Tennessee, 1998.

Lohmann, G. P.: A model for variation in the chemistry of planktonic foraminifera due to secondary calcification and selective dissolution, Paleoceanography, 10, 445-457, 1995.

Marshall, J., Adcroft, A., Holl, C., Perelman, L., and Heisey, C.: A finite-volume, incompressible Navier Stokes model for studies of the ocean on parallel computers, J. Geophys. Res., 102, 57535766, 1997a.

Marshall, J., Hill, C., Perelman, L., and Adcroft, A.: Hydrostatic, quasi-hydrostatic, and nonhydrostatic ocean modeling, J. Geophys. Res., 102, 5733-5752, 1997 b.
Mehrbach, C., Culberson, C. H., Hawley, J. E., and Pytkowicz, R. M.: Measurement of the apparent dissociation constants of carbonic acid in seawater at atmospheric pressure, Limnol. Oceanography, 18, 897-907, 1973.

Millero, F. J.: The thermodynamics of the carbonate system in seawater, Geochim. Cosmoschim. Acta, 59, 661-677, 1995.

Milliman, J. D.: Production and accumulation of calcium carbonate in the ocean: Budget of a nonsteady state, Global Biogeochem. Cycles, 7, 927-957, 1993.

Milliman, J. D. and Droxler, A. W.: Neritic and pelagic carbonate sedimentation in the marine environment: Ignorance is not bliss, Geologische Rundschau, 85(3), 496-504, 1996.

Milliman, J. D., Troy, P. J., Balch, W. M., Adams, A. K., Li, Y. H., and Mackenzie, F. T.: Biologically mediated dissolution of calcium carbonate above the chemical lysocline?, Deep Sea-Res. I, 46, 1653-1669, 1999.

Mucci, A.: The solubility of calcite and aragonite in seawater at various salinities, temperatures and one atmosphere total pressure, Amer. Jour. Sci., 283, 780-799, 1983.

NOAA - National Geophysical Data Center: Seafloor surficial sediment descriptions (Deck41), http://www.ngdc.noaa.gov/mgg/ geology/deck41.html, 2004.

Nelson, M. N., Tréguer, P., Brzezinski, M. A., Leynaert, A., and Quéguiner, B.: Production and dissolution of biogenic silica in the ocean: Revised global estimates, comparison with regional data and relationship to biogenic sedimentation, Global Biogeochem. Cycles, 9, 359-372, 1995.

Rickert, D., Schlüter, M., and Wallmann, K.: Dissolution kinetics of biogenic silica from the water column to the sediments, Geochim. Cosmoschim. Acta, 66(3), 439-455, 2002.

Sabine, C. L., Key, R. M., Feely, R. A., and Greeley, D.: Inorganic carbon in the Indian Ocean: Distribution and dissolution processes, Global Biogeochem. Cycles, 16, 1067, doi:10.1029/2001GB001639, 2002.

Sarmiento, J. L., Dunne, J., Gnanadesikan, A., Key, R. M., Matsumoto, K., and Slater, R.: A new estimate of the $\mathrm{CaCO}_{3}$ to organic carbon export ratio, Global Biogeochem. Cycles, 16(4), 1107, doi:10.1029/2002GB001919, 2002.

Schiebel, R.: Planktonic foraminiferal sedimentation and the marine calcite budget, Global Biogeochem. Cycles, 16, 1065, doi:10.1029/2001GB001459, 2002.

Schlitzer, R.: Electronic atlas of WOCE hydrographic and tracer data now available, Eos Trans. AGU, 81(5), 45, 2000.

Schott, F., Meincke, J., Meinecke, G., Neuer, S., and Zenk, W.: North Atlantic 1999, Cruise No. 45, 18 May-4 November 1999, METEOR-Ber., University of Hamburg, 00-4, 161 pp, 2000.

Takahashi, T., Broecker, W. S., Bainbridge, A. E., and Weiss, R. F.: Carbonate Chemistry of the Atlantic, Pacific and Indian Oceans: The results of the GEOSECS Expeditions, 1972-1978, Technical Report No 1, CV-1-80, Lamont-Doherty Geological Observatory, Palisades, New York, 15p, 1980.

Wollast, R.: The relative importance of biomineralization and dissolution of $\mathrm{CaCO}_{3}$ in the global carbon cycle, Bull Inst. Ocean Monaco Spec., 13, 13-35, 1994. 